\title{
Green Corporate Leadership (GrCL) to Improve Enforcement on Criminal Liability of Non-Legal Entity Corporations for Environmental Pollution and Destruction
}

\author{
Herlina Manullang ${ }^{1}$, P. L., Rika Fatimah ${ }^{2}$, \& Alvi Syahrin ${ }^{1}$ \\ ${ }^{1}$ Faculty of Law, Universitas Sumatera Utara, Indonesia \\ ${ }^{2}$ Faculty of Economics and Business, Universitas Gadjah Mada, Indonesia \\ Correspondence: P.L., Rika Fatimah, Faculty of Economics and Business, Universitas Gadjah Mada, Jl. Sosio \\ Humaniora No. 1 Bulaksumur, Yogyakarta, Indonesia.
}

Received: January 9, 2015

doi:10.11114/ijsss.v3i2.701
Accepted: January 23, 2015

Available online: February 27, 2015

URL: http://dx.doi.org/10.11114/ijsss.v3i2.701

\begin{abstract}
The environmental pollution and destruction by non-legal entity corporations normally occurs in the context of business operations, and is a consequence of the authority or business owner's failure to fulfill or negligence in performing their obligations to preserve the environment. The authority or business owners for their approach to lead the business operation shall bring about an interesting discussion with regard to enforce criminal liability of green issues. This study needs to highlight how the enforcement shall conduct to the non-legal entity corporations despite of by corporation or by individual. In addition, this study also argues how the green leadership shall in balance to build the green practice within value by corporate and leadership (GrCL). In addition, GrCL also integrated to the Environmental and Protection and Management (EPM) that has regulated the criminal liability of non-legal entity corporations for engaging in environmental pollution and destruction. However, EPM in practice is still difficult to prove the causality between problems in the business structure and the concrete behaviors or acts committed. Therefore, a new approach by having GrCL shall bring a comprehensive discussion not only by law but also by real implementation.
\end{abstract}

Keywords: criminal liability, non-legal entity corporation, environmental pollution and destruction, green leadership

\section{Introduction}

The role of corporations or business entities in the era of globalization requires a broadening of interdependence between countries, and they become a vital facility that fulfills the necessities of the people. Corporations or business entities have indeed been the backbone of world economy, but in their operations these corporations or business entities tend to conduct things against the ethics and law to obtain maximum profits. It is this profit-seeking motivation that eventually drives corporations to engage in criminal activities related to environmental and food pollution, and forbidden drugs, environmental safety and workplace conditions (Cheong, Neil, \& Stanley, 2012).

In the last decade there have been claims that the activities of corporations or business entities have had detrimental impacts to humans' wellbeing and caused violations of basic human rights. As specified in the first principle of the United Nations Global Compact, corporations must support and respect the protection of international basic human rights. In other words, it can also be said that in the context of running a company, conducting company activities, operating a business, and managing a company's relation with another party, there is surely a risk or potential of a negative impact to the protection and observance of basic human rights. However, on the other hand, it also needs to be realized that the existence of corporations or business entities provides an opportunity or can be used as a means to support or promote the concept of protection and observance of basic human rights aside from developing business and economy.

Although the currently applied Criminal Code comes from Dutch's Wetboek van Strafrecht of 1886 based on principle of concordance and thus is pointed for just individual (natural person), business entities or corporations are not considered as criminal legal subject. However, in criminal regulations out of Criminal Code, business entities or corporations have been acknowledged as criminal legal subject and could be treated based on criminal law, namely Emergency Article No. 7 of 1955 on Economic Criminal Act, Article No. 5 of 1997 on Psychoactive Drugs, etc, even in 
Criminal Code Draft currently discussed by government and People's Representatives Council also determines that the criminal legal subject includes individual persons (natural persons) and corporations (legal persons) (Kristian, 2013).

Apart of having impact to the human being, nowadays, any business operations shall also consider impact to the environmental and sustainability which can be refers as 'green issues' (Bass, 2000). In business, two significance approach need to be execute with regard to accommodate the green issues within the business operations. First is the real practice of the corporation or business policy and goals-(1) corporate approach. Second, a mindset of emotional and mental perspectives, values and capacities through the leader-(2) leadership approach. However, enforcement to the green issues is not only applied within the corporate or business operations but also need to be inline within the law and regulation of one country.

In Indonesia, one of the regulations that specify the criminal liability of corporations or business entities is Law No. 32 of 2009 on Environmental Protection and Management (here after referred to as the EPM Law). This can be seen in the content of Article 116, which adopts the vicarious liability principle (the imposition of punishments on a party for another party's act, only based on the relation between the two parties). According to EPM Law stating "everyone's duty to preserve and overcome pollution and environmental destruction" and "having a duty to distribute true and accurate information in favor of environmental management" and EPM Law Article 116, this makes the concept of criminal liability of business entities or corporations is imposed to business entities or corporations and their managers (directors, the managers in charge of environmental management, even shareholders and commissioners (Hamilton, 2001) simultaneously, concerning such activities and/or business attempts causing pollution and/or environmental destruction. This can be seen in the content of Article 116, which adopts the vicarious liability principle.

\section{Non-Legal Entity Corporations \& Green Corporate Culture (GrCC) Approach for Enforcement to the Criminal Liability}

Corporate or business operations are closed related to the vision and value of its leader. Process to transform the leader's vision and value could motivate their management and staff to proactively accomplish their own jobs and goals (Elkins \& Keller, 2003). Therefore, having law and regulations accordingly to the green issues is not adequate. Need more comprehensive and holistic implementation within the corporate or business operations. The non-legal entity corporations obviously need kind of approach to accommodate the green issues. Green Corporate Culture (GrCC) approach shall bring about a more comprehensive and holistic practices with regard to the green issues. If law and regulation is 'the after action' then the GrCC is 'the before action'. Three (3) green practices under the GrCC are (1) Policy Making; (2) Growth-Oriented Practice; \& (3) Sustainability Goals (refer to Figure 1). Each of the practices is in line with the law and regulation with regard to the enforcement criminal liability of non-legal entity corporations. Figure 1 illustrates how "the before action" of green issues to be incorporate in corporate culture. Starting from how the corporations form and design their corporate rules/policy to accommodate the green issues. After the policy making needs practice with the continuous improvement of the green practice. The continuous improvement will lead to more sustain goals of green practice. As a result, the GrCC will be more in a comprehensive and holistic way to care and act of the green issues.



Figure 1. Green Corporate Culture (GrCC) for Enforcement to the Criminal Liability of Non-Legal Entity Corporations 
In the initial development of the issue of criminal legal subject and criminal liability, it is universally acknowledged that the criminal legal subject is an individual (natural person). In the field of law there was even a commonly accepted principle at the time, namely universitas delinquire non potest that means it is impossible that corporations conduct a criminal act. This is influenced by the view of Von Savigny that corporations or business entities as a legal subject are a legal fiction accepted in civil law but are not suitable to be transferred as so to criminal law (Remmelik, 2003). In criminal law, in order to be called a criminal act, a conduct must meet some requirements, i.e. both actus reus and mens rea are present and the principle actus nonfacit reum, nisi mens sit rea applies. Therefore, only humans that can conduct a criminal act given that only humans make fault/have mens rea or evil mind or evil will. Having the GrCC approach, the theory argues that humans are the subject matter to the criminal act of green issues namely environmental pollution and destruction therefore practices to enforce the first GrCC practice that is Policy Making. The final product of corporate policy shall be recognizing as corporate or business operations. The policy making is conduct by human but as result of the policy making is a corporate policy itself which directly impact to any criminal act conducted. Therefore, having GrCC approach in the corporate or business operations shall bring a preventive action that the human need to be aware to the green issues in every step of policy making. The final product of the policy making can be extended to the corporate policy.

Although at the time corporations or business entities were not yet recognized as a criminal legal subject, it does not mean that corporate crimes never happened. The second and third practice of GrCC approach is Growth-Oriented and Sustainability Goals shall accommodate to this matters. If the culture within the corporate is considering the growth and sustainability goals then some environmental pollution and destruction can be avoid accordingly.

Referring to JE Sahetapy, crimes by corporations or business entities are actually not a new thing; only the packaging, form, and realization that are novel. Crimes by corporations or business entities have occurred since more than three thousand years ago in 14th century BCE Egypt. In ancient times in Greece, business entity/corporate crimes also existed, for instance, the case of Alcmaendos who was trusted to build a temple with marbles, but instead he built it with cement covered with marbles (Sahetapy, 1994). Such business entity/corporate crimes happen from time to time until today. Cases of business entity/corporate crimes such as environmental pollution have happened as well in Indonesia, including environmental pollution cases in Buyat Bay presumed to be caused by PT Newmont Minahasa Raya, PT Dongwoo Environmental Indonesia in Bekasi, the forest fire case associated to PT Adei Plantation \& Industri and presumed to be caused by the General Managers collectively, the Exxon Mobil Oil case in Indonesia.

The international conventions regulating business entities or corporations (legal persons) as a criminal legal subject include the United Nations Convention Against Transnational Organized Crime (Palermo Convention, 2000) in Article 10 on Liability of Legal Person, United Nations Convention Against Corruption 2003 in Article 26 on Liability of Legal Persons, and International Convention for the Suppression of the Financing of Terrorism 1999 in Article 5 on Liability of Legal Entity (Suseno, 2009).

\section{Indonesian Law Enforcement on the Criminal Liability of Non-Legal Entity Corporations by Using Green Leadership Approach}

Both individual and corporations or business entities are strongly driven by the leader. Leadership plays a crucial role for the development of corporate or business operations (Chen \& Chang, 2013). Three (3) practices of the Green Leadership are (1) Mindset Development; (2) Behavior-Action; and (3) Inspirational Motivation (refer to Figure 2). As refer to 'the before action', corporate or business operations shall prepare the leadership approach through a mindset as a basis knowledge of all green practices across the corporation. Mindset then in action shall reflect through green behavior in anytime of green action. Continuous practice shall lead to long-lasting inspirational motivation for both individual and corporations or business entities. However, as explained before, an internal action of the corporation or business entities shall not adequate. Law and regulation also need to refer as law enforcement in order to firmly conduct the implementation to the green practices under a proper legal form. 


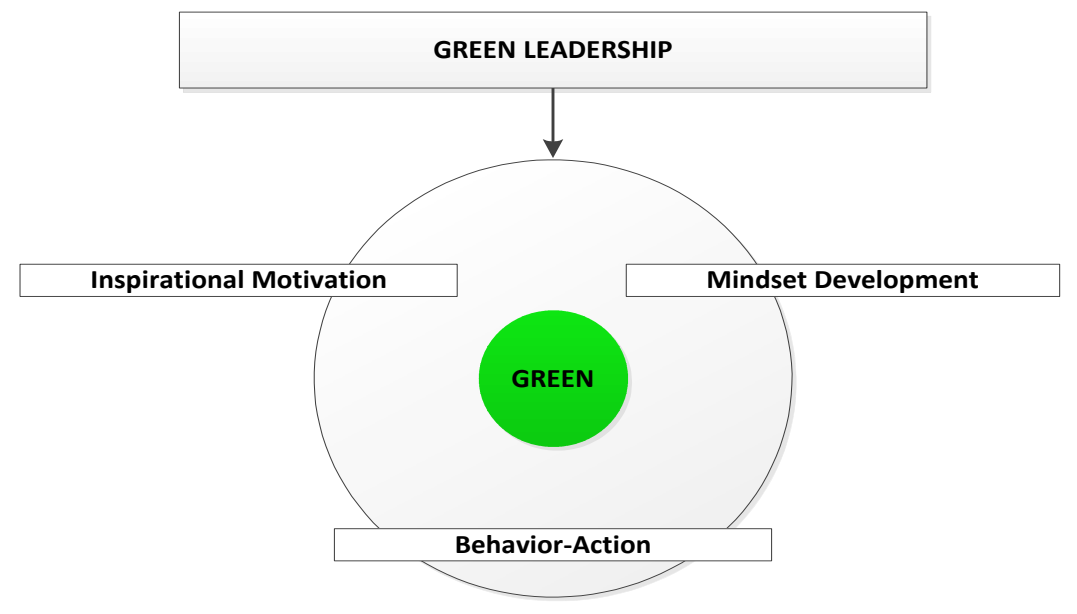

Figure 2. Green Leadership for Enforcement to the Criminal Liability of Non-Legal Entity Corporations

Considering the legal form, Indonesian criminal law defines corporation or business entity broadly. According to Indonesian criminal law, corporation or business entity is defined differently from corporation and business entity in civil law. The definition of corporation according to criminal law is broader than that under civil law. According to civil law, a legal subject, which is one who can or has the authority to conduct a legal action civil law, for instance making an agreement, may be an individual person (human or natural person) or a legal entity (legal person), therefore what is meant by a corporation or business entity is a legal entity (legal person).

However in criminal law, corporation or business entity covers legal entity corporations that include limited companies, foundations, cooperatives, or associations that have been certified as legal entities and non-legal entity corporations that include firms, limited partnerships or CV, and partnerships or maatschaap (Sjahdeni, 2007). As for the definition of "setiap orang" (every person) in Article 1 Section (32) of the EPM Law, it means an individual or a corporation either legal entity or non-legal entity.

The liability of corporations or business entities under criminal law is not determined through an in-depth research process by experts, but as a result of the tendency of the legal formalism. The principle of the liability of corporations or business entities has developed through the role of the court without any theory justifying it. The judge in the common law system makes an analogy with a human legal subject, so that a corporation or business entity also has a legal identity and a control of the assets of the managing individuals who set it up (Weissmaan \& Newman, 2007).

The liability of corporations or business entities is based on the principle of respondeat superior, which determines that a corporation or business entity itself cannot commit wrongdoing. Only can agents acting for and on behalf of a corporation or business entity commit wrongdoing. Therefore, the liability of corporations or business entities imposes a form of punishment on a person/agent's conduct (vicarious liability), in which it is responsible for the wrongdoing committed by the agent. This principle is a result of civil law applied in criminal domain. Vicarious liability usually applies in civil law to illegal conducts based on respondeat superior (Sjahdeni, 2007). There are three requirements that must be met to impose liability on a corporation or business entity, namely: its agent commits a crime; the crime is still in the scope of his/her duty; and the crime is committed to the advantage of the corporation or business entity (Khana, 2000).

The respondeat superior principle results in three standards of criminal liability of corporations or business entities, namely direct corporate liability, strict liability, and vicarious liability. In direct corporate criminal liability, a corporation commits a crime directly through its agents that are closely related to the corporation or business entity, acting for and/or on behalf of the corporation or business entity. Direct corporate or business entity criminal liability requires that the agent's conducts are committed still in the occupational scope of the corporation or business entity (Sue Titus Reid in Colvin, 1995). Direct corporate criminal liability is closely related to the principle of identification, which basically recognizes a certain conduct of a corporation or business entity's agent as far as the conduct is related to the operation of the corporation or business entity, and such conduct is considered to be a conduct of the corporation or business entity itself (Colvin, 1995).

Strict Liability is imposed on a criminal act without requiring fault on the doer for one or more actus reus (Russel, 2006). Strict Liability is liability without fault. It can be emphasized that in a criminal act for which strict liability can be imposed, it needs only a presumption of guilt or the doer's (the accused) knowledge to impose criminal liability on 
him or her. So, it disregards the mens rea as the essential element of strict liability is the actus reus (action) so the one that needs to be proven is the actus reus (action), not the mens rea (criminal intent) (Hanafi, 1997).

Vicarious liability (substitute liability) is defined as legal liability imposed on a person for wrongdoing committed by another person (Sue Titus Reid in Colvin, 1995). This standard is limited for certain circumstances in which the employer (corporation or business entity) is responsible for a worker's wrongdoing that is committed in the scope of his or her work (Clarkson, 1998). The reasoning behind this standard is that the employer (corporation or business entity) has control and authority over its workers and the advantage a worker obtains directly benefits the employer (corporation or business entity). The principle of an employment relation under vicarious liability is called the delegation principle, which means it is related to the authorization for a person to manage a business. The business owner runs the business directly, but he or she fully delegates a manager to take care of his or her corporation or business entity. If the manager commits an illegal act, the business owner (delegator) is liable for it (Clarkson, 1998).

When a corporation or business entity is declared criminally liable for a criminal act in Indonesia, according to Mardjono Reksodiputro (Reksodiputro, 1984) there are three possibilities for it as a criminal legal subject related to its criminal liability, namely (1) The manager of the corporation as the doer and the corporation as the liable party; (2) The corporation or business entity as the doer and the manager as the liable party; (3) The corporation or business entity as the doer and the liable party.

Therefore, under this liability it is still possible to prosecute and sentence individuals, including managers, aside from the corporation or business entity itself. Nevertheless, the role of humans or individuals is still significant and thus it is necessary that they are considered as a subject of prosecution.

How do make corporations and other organizations comply? They have no arms, no legs, no conscience-if you cut them, they don't bleed, you can't fine them enough to get their attention.... Individuals make a difference in corporations. They are not nameless and faceless. They can go to jail. We can go to get their attention (Arbuckle, 1993).

Managers are individuals with a social position or power, at least in the scope of the company where they work. Therefore, while enjoying their social position, they need to also be given responsibility as expressed in the saying: "where social power exists, so does responsibility" (Gunter, 1994).

\section{Criminal Liability of Non-Legal Entity Corporations in the Environmental Protection and Management (EMP) Law No.32 of 2009 \& Green Corporate Leadership (GrCL)}

Section four discuss about two important matters are Environmental Protection and Management (EMP) and Green Corporate Leadership (GrCL). Both topics are driven to discuss how to enforce the criminal liability in the way of 'before and after action'.

\subsection{EMP Law No.32 of 2009 for the Law Enforcement to Criminal Liability of Non-Legal Entity Corporations}

As briefly mentioned before, 'the after action' is closely discussed with regard to the law form. In imposing criminal liability on legal entity and non-legal entity criminal corporations for environmental criminal acts, according to Muladi (1998) the following need to be considered (1) Corporation or business entity includes both legal entity and non-legal entity such as organization etc; (2) A business entity can be private (private juridical entity) or public (public entity); (3) If it has been declared that the environmental criminal act is committed as an organization, the natural person (manager, agent, or employee) and the corporation can be sentenced, either separately or collectively (bipunishment provision); (4) There is a fault in the management of the corporation or business entity that is called breach of statutory or regulatory provision; (5) Corporate liability is imposed regardless of whether the responsible persons in the corporation are identified, prosecuted, and sentenced; (6) Any criminal sanction and action that can basically be imposed on corporations or business entities, except death sentence and imprisonment. In this case it needs to be noted that in the United States, there have been applied what are called "corporate death penalty" and "corporate imprisonment", that forbid a corporation or business entity to operate in certain business areas and other restrictions on its operations; (7) The imposition of a criminal sanction on a corporation or business entity does not expunge individual faults; (8) The criminalization of a corporation or business entity should consider the state of control in the corporation, whether it is through managerial policies or through decisions made by the managers (corporate executive officers) who have the authority to decide (power of decision) and accepted by the corporation or business entity.

This concept of criminal liability of legal entity corporations and non-legal entity corporations has been formulated in the Indonesian legal norms on environment, especially in the EPM Law. In the EPM Law criminal liability of corporations is specified in Article 116 to Article 119. Article 116 of the EPM Law defines the criteria for corporate liability and who must take responsibility. As specified in Article 16 of the EPM Law, corporate liability occurs in one of the following situations, namely; (1) a criminal act is committed for or on behalf of the corporation or the person who 
gives the instruction for the criminal act or the person who operates as a leader in the criminal act, (2) the criminal act is committed by a person who under an employment relation or another kind of relation acts in the corporation's scope of work. Because a corporation cannot operate without humans, the physical driver is still humans, i.e. individuals on behalf of the corporation or individuals under an employment relation, such as employees, or another kind of relation, such as a contract agreement.

The explanation for Article 116 Section (1) of the EPM Law requires an interpretation to understand the meaning of the phrase "the person who gives the instruction for the criminal act" or "the person who operates as a leader in the criminal act." "The person who gives the instruction for the criminal act" must be understood as the individual who runs and implement "the management" of the corporation. In other words, the phrase "the person who gives the instruction for the criminal act" or "the person who operates as an activity leader in the criminal act" in the context of criminal liability of corporations or business entities shows the liability of the corporation's managers or functionaries. It means that the phrase "the person who gives the instruction for the criminal act or the person who operates as a leader in the criminal act" as specified in Article 116 Section (1) of the EPM Law points to the liability of the corporation's managers as individuals. The managers of a corporation or business entity can be imposed criminal liability as an individual, if the environmental criminal act is committed by, for, or on behalf of the corporation or business entity.

The provision of Article 116 of the EPM Law opens a possibility that if a non-legal entity corporation or business entity commits a criminal act, the prosecution is not only brought against the corporation or business entity but also against the persons instructing the act and the persons concretely and directly lead the criminal act. This means that the managers as the real instructor of and/or leader in the act can be held liable for the act committed by the corporation or business entity.

The managers of the corporation or business entity can be seen "as the person who gives the instruction for the criminal act," or the managers of the corporation can be seen "as the person who operates as a leader in the criminal act," meaning that a manager of the corporation or a manager of the business entity can be seen as the person who operates as a leader in the criminal act.

Being "the person who gives the instruction for the criminal act and the person who operates as an activity leader in the criminal act" may make a manager open to two prosecutions. Prosecuting a manager as the person who gives the instruction for a criminal act and as the person who operates as a leader in the criminal act will be against our sense of justice and the principle of ne bis in idem will prevent two prosecutions for a person (manager) for two different roles ("as the person who gives the instruction for the criminal act and as the person who operates as an activity leader in the criminal act"), which means that for the prosecution of the manager, one role must be chosen between the person who gives the instruction for the criminal act $o r$ the person who operates as an activity leader in the criminal act.

A person in his or her function in the organization of a non-legal entity corporation or business entity must take action to prevent illegal conducts, and he or she does not do it, the person does not lose his or her leadership position in the context of guiding the conduct of the corporation or business entity (although factually the illegal conduct may be committed by another employee). In such situation, the person can be considered as a leader. A person can also be considered as a factual leader in a criminal act by a corporation or business entity if he or she is aware of the criminal act in question but does not take action to prevent it and thus factually accepts the criminal act.

Article 116 Section (1) sub a of the EPM Law using the word "atau" (or) between the phrases "the person who gives the instruction for the criminal act" and "the person who operates as the leader in the criminal act" is a clarification to prevent a manager of a non-legal entity corporation or business entity facing two prosecutions for an environmental criminal act.

According to Remmelik (2003) in practice "who gives the instruction" or "who operates as the leader" means a manager. A person can be said to factually lead the corporation or business entity's criminal act if he or she is aware of it happening, or if he or she does not take action at all to prevent the act being committed by his or her subordinates, although the person has the authority to do that and is able to perform the prevention, and he or she even consciously lets the illegal act be committed although there is an opportunity to prevent it.

\subsection{Green Corporate Leadership (GrCL): Balancing the Leadership and Corporate Value in the Enforcement to the Green Practice}

In previous discussion, already mention with regard to the Green Corporate Culture (GrCC) and Green Leadership. Here, the integration needs to be done in order to have a balance implementation among the two approaches. Green Corporate Leadership (GrCL) shall be the answer for that matter. The enforcement of green practice lies on both individual and corporations or business entities. Any of one is not progressing in the green practice shall affect to the 
others. Both need in a balanced implementation. All practice the six of them shall support each other in order to have an optimum enforcement of the green practices (refer to Figure 3).

The managers of a corporation or business entity are individuals who hold a social position or power, at least in the scope of the company where they work. Those who can be categorized as corporation managers are (1) Those who according to the articles of association formally operate the management of the corporation; (2) Those who according to the corporation's articles of association are not managers, but officially have the authority to conduct acts that legally bind the corporation based on: (a) A designation by the managers to hold a position with an authority to take action autonomously within the scope of the duties and obligations attached to the position to be able to conduct a corporation-binding legal act; (b) A granting of power by the managers as specified in Section (1), to conduct acts that legally bind the corporation.; (3) Those who are instructed by those mentioned in paragraph (a) and (b) to run or operate the management of the corporation.

As refer above, how so important that individuals of namely manager shall balance both corporate culture and leadership in his/her action with regard to the green practice. In addition, managers are a corporation or business entity's organ that operates the management of the related corporation or business entity in accordance with the articles of association, including those who in reality have the authority and participate in making the corporate policy that can be categorized as a criminal act. Therefore, every individual who is granted the organizational or operational responsibility for the specific act or who has the obligation to prevent the illegal act by the corporation, or in this case to perform his or her obligation to ensure environmental protection and management, can be imposed criminal liability.

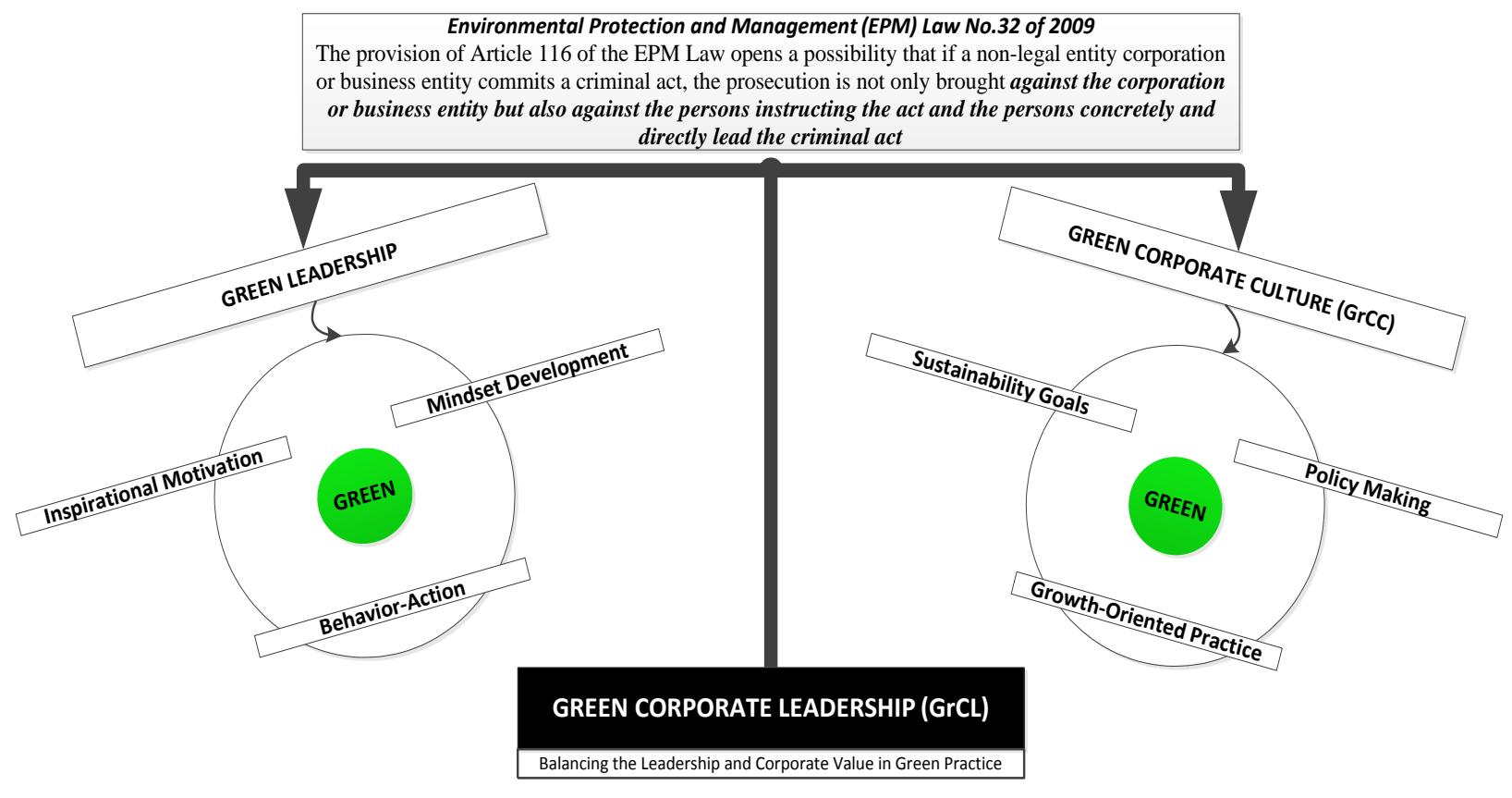

Figure 3. Green Corporate Leadership (GrCL) for Enforcement to the Criminal Liability of

Non-Legal Entity Corporations: Balancing the Leadership and Corporate Culture in the Green Practices

Furthermore, in Article 116 Section (2) concerning the phrase "If the environmental criminal act.... Committed by a person, who is based on an employment relation or another kind of relation acting within the corporation's scope of work, the criminal sanction is imposed on the one who gives the instruction or the leader in the criminal act regardless of the criminal act being committed individually or collectively." Considering the provision of Article 116 Section (2) of the EPM Law along with the explanation, there is no clarification on the phrase "based on an employment relation" and the phrase "or another kind of relation," so legal interpretations on the phrases are needed.

According to Sutan Remy Sjahdeni (2007) the statement "who is based on an employment relation or another kind of relation" shows that there are two kinds of persons, the first being those who are "based on an employment relation" and the second being those who are based on "another kind of relation." The relation meant in the two phrases must be interpreted as "the relation with the related corporation or business entity." 
Moreover, Sutan Remy Sjahdeni (2007) states that "persons with an employment relation" are those bound in an employment relation as a manager or employee, based on (1) The articles of association and its amendments; (2) Recruitment as an employee and an employment agreement with the corporation or business entity; and (3) A contract as an employee.

As for "individuals under another kind of relation", it means individuals in a relation other than an employment relation with the corporation or business entity. They, among others, represent the corporation or business entity to commit legal acts for and on behalf of the related corporation or business entity based on (1) A granting of power; (2) An agreement with a granting of power (power is not granted); and (3) A delegation of authority.

Article 116, Section (2) of the EPM Law indicates that in the determination of guilt, this law follows an identification system by identifying that individuals who have an employment relation or a relation other than employment with the corporation are the directing mind of the corporation or business entity.

\section{Conclusion}

The provision of Article 116 of the PME Law specifies several legal implications. First, non-legal entity businesses are not free from criminal responsibility in case of conducting activities or causing conditions that qualify for environmental crimes. Second, based on the principle of vicarious liability, the leadership of a business organization or corporation or anyone assigning a task or instruction is responsible for activities conducted by their subordinates or employees. The criminal responsibility should then be expanded to include activities done based on an employment relation or other kinds of relation.

In addition, if law and regulations is aim for 'the after action' with regard to green issues namely environmental pollution and destruction, then Green Corporate Leadership (GrCL) is 'the before action'. Balancing the nature of individual and corporations or business entities, GrCL accommodate the green issues into real practices. How to view the green issues and transform into a comprehensive and holistic approach into the real practice is the main goals of GrCL purposed. GrCL meant to provide a view point breeding the law form and management practices into a dynamic corporate culture and business operations.

\section{Acknowledgements}

This paper is presented in Workshop and Coaching on Writing Publication in International Journal (WCWPIJ) 2014, Malaysia. Therefore, the authors express their gratitude to Think Smart Scholar (TS Scholar) for the event and Prof. Tan Kamello from Universitas Sumatera Utara for his valuable inputs during the preparation and improvement processes of this article.

\section{References}

Arbuckle, J. G. (1993). Environmental Law Handbook. Government Institute Mc Rockfille, 56.

Bass, B. M. (2000). The Future of Leadership in Learning Organizations. Journal of Leadership \& Organizational Studies, 7(3), 18-40. http://dx.doi.org/10.1177/107179190000700302

Chen, Y. S., \& Chang, C. H. (2012). The Determinants of Green Product Development Performance: Green Dynamic Capabilities, Green Transformational Leadership, and Green Creativity. Journal of Business Ethics, 116(1), 107-119. http://dx.doi.org/10.1007/s10551-012-1452-x

Cheong, W. C., Neil, M., \& Stanley, Y. (2012). Criminal Law in Malaysia and Singapore, LexisNexis, Singapore, Malaysia, Hongkong, India, 1015.

Clarkson, C. M. V. (1998). Understanding Criminal Law, Second Edition, London: Sweet \& Maxwell. 44.

Colvin, E. (1995). Corporate Personality and criminal Liability. Criminal Law Forum. http://dx.doi.org/10.1007/BF01095717

Elkins, T., \& Keller, R. T. (2013). Leadership in Research and Development Organizations: A Literature Review and Conceptual Framework. The Leadership Quarterly, 14(2003), 587-606.

Gunter, H. (1994). Summary in die Strafrechtliche Verantwortlichkeit van Unternehmen, Nomas verlagsgesellschaft, 320 .

Hanafi. (1997). Strict Liability dan Vicarious Liability dalam Hukum Pidana. Yogyakarta: Lembaga Penelitian, Universitas Islam Indonesia, 63-64.

Hamilton, W, (2001), Cases and Materials on Corporation Including Partnership and Limited Liability Companies, American Casebook Series, West Group, 298-355. 
Kristian. (2013). Hukum Pidana Korporasi Kebijakan Integral (Integral Policy) Formulasi Pertanggungjawaban Pidana Korporasi Di Indonesia,Bandung, Nuansa Indah, 46.

Russel, H. (2006). Criminal Law. London: Oxford University Press, 403.

Khana, V. S. (2000). Corporate Liability Standards; When Should Corporation Be CriminalityLiable. American Law Review. 1242-1243.

Muladi. (1998). Prinsip-Prinsip Dasar Hukum Pidana Lingkungan Dalam Kaitannya denganUndang-Undang No.23 Tahun 1997. Jurnal Hukum Pidana dan Kriminologie, l(1).

Reksodiputro, M. (1984). Dampak Kejahatan Korporasi Untuk Pembangunan. In Kemajuan Pembangunan Ekonomi dan Kejahatan. Jakarta: Pusat Pelayanan Keadilan dan Pengabdian Hukum Universitas Indonesia.

Remmelik, J. (2003). Hukum Pidana. Jakarta: PT Gramedia Pustaka Utama, 208(1), 97-98.

Sahetapy, J. E. (1994). Kejahatan Korporasi. Bandung: Eresco.4.

Sjahdeni, S. R. (2007). Pertanggungjawaban Pidana Korporasi. Jakarta: PT Grafiti.42-43.

Suseno, S. (2013). Hukum Pidana Indonesia Perkembangan dan Pembaharuan. Yogyakarta: Rosda.209.

Weissmaan, A., \& David, N. (2007). Rethinking Criminal Liability. Indiana Law Journal, 82(411).

\section{Appendix}

Business Entity is a unit of Juridical (legal), technical, and economical matter aiming for seeking profit. In general, business entity can be classified into 2 (two) part, namely legal entity corporation and non-legal entity corporation. At a glance, there is no difference between them. However, there are two fundamental differences: first, on the procedure of the entity's establishment, and second, on the burden of liability. On the legal entity corporation, its establishment surely needs government legalization, for instance, limited companies. As for non-legal entity, it does not need the requirement of government legalization, for instance, limited partnerships, firms and partnership (maatschap). Also as for non-legal entity corporation, if the business goes bankrupt, the liability would impose its individual wealth, while the legal entity one would impact as much as deposited capital or share owned.

Criminal Liability is a process where an objective denunciation (verwijtbaarheid) is a continued towards the acts declared as criminal acts by criminal law and the the perpetrator as a legal subject meeting the criteria to be convicted.

Green Corporate Leadership is in the attempt in environmental management; corporations have responsibilities in formulating environmental; policy.

Environmental pollution is the unification or ingestion of living organisms, substances, energy, or other components into the environmental quality determined.

Environmental Destruction is an action that brings about direct or inderect change towards environmental biochemical and/or biological quality so it exceeds the criteria of environmental destruction.

Corporate culture is reflects the behavior, values, dreams, assumptions, hopes, commitments,performances, knowledge, competence, recognition, and rewards systems, innovation, and communications that exist within a company.

This work is licensed under a Creative Commons Attribution 3.0 License. 